\title{
PHILOSOPHY OF EDUCATION
}

UDC 378:328.185(474.5)

DOI https://doi.org/10.26661/hst-2019-1-78-04

\section{HIGHER EDUCATION COMMUNITY DOCUMENTS AVAILABLE TO ACADEMIC COMMUNITY AIMING AT INCREASING ACADEMIC INTEGRITY LITERACY AND PREVENTING CORRUPTION OF LITHUANIA}

\author{
MEJERYTE-NARKEVICIENE, KRISTINA \\ Lithuanian Sports University (Kaunas, Lithuania) \\ E-mail: kristina.mejeryte@1su.lt, ORCID 0000-0003-0629-3265 \\ KARANAUSKIENE, DIANA \\ Lithuanian Sports University (Kaunas, Lithuania) \\ E-mail: diana.karanauskiene@1su.lt, ORCID 0000-0002-9346-487X
}

CESNAITIENE, VIDA

Lithuanian Sports University (Kaunas, Lithuania)

E-mail: vida.cesnaitiene@ 1su.1t, ORCID 0000-0003-0996-0449

Lietuvos sporto universitetas Sporto 6 Каунасский уезд, 44221 Kaunas, Lithuania

\begin{abstract}
Recently, academic integrity literacy and anti-corruption issues have become very topical in education system. Lithuanian domestic and foreign policy is interested in reducing corruption in order to improve Lithuania's international image in all sectors. Research conducted in recent years lacks the anti-corruption theme of public education and the image of impunity is relevant. In the education system, corruption takes many forms and dimensions [37]. In all cases, corruption challenges the quality of education and thus the socio-economic development of the society.

The research aim was to analyse documents available to higher education communities aimed at enhancing academic integrity literacy and prevent possible manifestations of corruption in higher education systems. The objectives of the research: to analyse documents which are available to higher education communities and related to academic integrity literacy, to assess the documents visibility and accessibility to the academic community and the public, to establish if the available documents were analysed and examined by the academic community members.
\end{abstract}

Analysis of recent research and publications. Academic integrity literacy and preventing corruption in higher education is a growing topic in educational research. I. Silova, M. Johnson, S. Heyneman (2007), E. Denisova-Schmidt (2016), highlights more how corruption affects the efficiency of the economy. R. Bikulciute and R. Mrazauskaitethe (2013) excluded the problems of academic integrity literacy. N.L. Rumyantseva (2005) represented the taxonomy of corruption in the higher education system. A.L. Osipian (2008), S. Tanaka(2001) G. Mohamedbhai (2015) and others, wrote the manifestations of hidden and open corruption or corruption forms.

Research methodology. Aiming at analysing the documents available to higher education communities to enhance academic integrity literacy and prevent possible corruption in the higher education system, analysis of these documents was carried out. Also, their visibility and accessibility to the academic community and the public was assessed. Quantitative research with students and teachers was used to establish how well the academic community members knew the aforementioned available documents.

(C) Kristina Mejeryte-Narkeviciene \& Diana Karanauskiene \& Vida Cesnaitiene, 2019 
Conclusion. On their websites, higher education institutions publish all documents that regulate their activities including studies, which allows to prevent or partially reduce the existence of not only visible corruption but also hidden forms of corruption. As a preventive measure in higher education, members should be made more aware of the code of ethics and internal rules of work. However, various forms, such as thematic training, seminars or surveys, should be used systematically to fight corruption.

Keywords: academic integrity literacy, academic integrity, corruption in higher education, hidden forms of corruption.

\section{INTRODUCTION}

Education is a fundamental human right and an engine of their personal, social and economic development. It is the guarantor of their better future as it enables people to live well, be dignified and useful to the society. It is the education of the people that largely determines the kind of society we are going to live in.

In the education system, corruption takes many forms and dimensions [37]. In all cases, corruption challenges the quality of education and thus the socioeconomic development of the society. Corruption not only destroys the academic achievements of higher education institutions, but it also damages the entire higher education system. The root causes of corruption lie in the lack of transparency and accountability.

Corruption in higher education is a growing topic in educational research. Nevertheless, research on this topic is still scarce. There are cases of corruption throughout the higher education system which seriously jeopardize its reputation: both for research and for graduate qualifications, no matter how guilty they are [38]. Higher education is closely linked to the economy; thus, corruption also affects the efficiency of the economy [31].
In recent years, the massification of higher education has become not only important to the global knowledge economy, but also to its quality [4]. Some higher education institutions are unable to cope with global competition, pressures, and are leaning towards a lack of academic integrity. Corruption often becomes an effective instrument for solving emerging problems, seeking both local and international recognition [4].

Some forms of corruption are specific to certain regions because they are closely linked to the regional, social and economic system of those regions, while others are universal. As a result of globalization processes, corruption that has come from other regions has been unidentifiable for some time. Some known cases of corruption take on a new form which also makes them invisible or less visible for a while.

Corruption encompasses three key aspects of higher education accessibility, quality and impartiality [21]. These problems are dealt with differently in each state.

The present study is grounded on the assumption that not all forms of corruption are deliberately concealed (e.g. bribery, illegal money charges, etc.). Some are simply invisible for a variety of reasons - lack of academic integrity literacy, stereotypes in the

Higher education community documents available to academic community aiming at increasing academic integrity literacy and preventing corruption of Lithuania 
society, indifference, acceptance of the situation, and others. Those reasons suggest that accessible information and education of the academic community and society members might be a powerful instrument to fight corruption and deal with the emerging problems.

The aim of the study was to analyse documents available to higher education communities aimed at enhancing academic integrity literacy and prevent possible manifestations of corruption in higher education systems, and to assess their visibility and accessibility to the academic community and the public. The study also aimed at establishing if the available documents were analysed and examined by the academic community members.

\section{METHODS}

Aiming at analysing the documents available to higher education communities to enhance academic integrity literacy and prevent possible corruption in the higher education system, analysis of these documents was carried out. Also, their visibility and accessibility to the academic community and the public was assessed.

Aiming at establishing how well the academic community members knew the aforementioned available documents, students and teachers from five Lithuanian universities and two Lithuanian colleges and Lithuanian students from two foreign universities and two foreign colleges were interviewed. A total of 600 subjects participated in the study.

RESULTS AND DISCUSSION
The rules governing permissible and acceptable behaviours are important and necessary for the existence and survival of each higher education institution. These may be statutes of higher education institutions, existing ordinances, orders, codes of academic and professional ethics, rules, regulations or other internal valid documents. According to the accepted documents, which clearly state the publicly declared procedures in the institution of higher education, the likelihood of one or another case of corruption significantly decreases. The members of each higher education institution follow a set of rules in their activities, especially in conflict situations, so it is essential to establish certain rules that help its members to deal ethically with the problems that arise. The Code of Ethics for Higher Education Institution is one of the key documents that helps to shape values such as integrity, honesty, discipline, responsibility, equal opportunities, etc. in higher education. It is not only an internal document regulating the decisions and activities of the higher education institution, it also performs external functions intended for a wider audience. With this document, the higher education institution has the opportunity to look at itself and the values it declares, while also providing such possibility to the public at large.

Higher education institutions oblige to adhere to academic ethics procedures and follow the Code of Academic Ethics in conflict resolution aiming at preventing unethical behaviours, defining responsibilities, 
increasing public confidence, and promoting as well as increasing transparency in higher education ethics. In order to ensure the transparency of the process, the Ministry of Education and Science of the Republic of Lithuania provided recommendations for codes of ethics as early as 2005 (Order of the Minister of Education and Science of the Republic of Lithuania, 2005), and since 2011 the Office of the Ombudsman for Academic Ethics and Procedures has been established. This service promotes research and educational institutions to follow the academic ethics principles and procedures. It also supervises and monitors their adherence to the codes of academic ethics. The controllers of the Office are obligated and authorized to cooperate with the institutions of research and education in solving problems related to violations of academic ethics and its procedures. The function of the controllers in the Office of Academic Ethics and Procedures is to investigate the complaints of applicants and on their own initiative to conduct investigations concerning the conduct of individuals who have or might have infringed the principles of academic integrity, academic freedom, academic impartiality, participation in competitions, ethical relationships etc. They also deal with complaints of misconduct in the field of academic ethics and procedures concerning the heads of administration and departments. They also analyse the codes of academic ethics of various institutions of higher education, provide recommendations regarding the development, implementation and improvement of the codes themselves and other measures of academic ethics (Resolution of the Seimas of the Republic of Lithuania, 2011).

The Report of the Controller of Academic Ethics and Procedures of the Republic of Lithuania on "Provision of Codes of Academic Ethics and Related Information in the Institutions of Higher Education" (2017), states that in most cases academic codes of ethics and the information on higher education academic ethics or other dispute resolution commissions is not officially available. However, after reviewing the websites of all Lithuanian state and non-state universities from the beginning of 2018 , it can be stated that all universities except for the LCC International University have provided codes of academic ethics on the university's website. On their website, they claim that LCC University adheres to all code of ethics and transparency principles, though they do not publicly disclose them. They also note that the activities of LCC University in Lithuania and the USA are constantly audited. LCC International University's official website contains only statute and governance bodies. It should be noted that the situation in the universities of applied sciences is slightly different. All state colleges have a code of ethics for academic and professional practices on their websites, and only some non-state colleges have publicly available codes of ethics. 
All major governing documents of higher education institutions, such as the university statute, strategic plans, financial performance reports and codes of academic and professional ethics, are publicly available on the websites of all state and nongovernmental universities. LCC International University does not make such documents publicly available on their website. In the majority of state and non-state universities, such documents are publicly available.

Study quality assurance documents and study regulations (regulations of studies, scholarship award procedures, credits for the study courses, final thesis preparation and defence regulations, internship practice organization and performance regulations, etc.) are also available to all on both state and non-state university websites except for LCC International University. Documents regulating studies are also publicly available in state colleges, and most non-state colleges do not publish them.

When assessing the composition or contact details of academic ethics or other dispute resolution panels on higher education websites, it is noted that all universities have provided such information, however some colleges have not done that yet. The aforementioned codes of academic and professional ethics do not specify exactly where the person seeking to report ethics violations should apply, so it is important to ensure access to full information. In this case, it is imperative that the higher education institution should be committed to publishing not only the code of ethics but also the contact details of the ethics commission.

It is noteworthy that on their websites, both public and nongovernmental universities are increasingly providing documents that increase transparency in higher education. It could potentially have been influenced by the Order of the Controller of Academic Ethics and Procedures No. V-16, approving "Guidelines for the Adoption, Implementation and Supervision of Codes of Academic Ethics for Higher Education and Research Institutions", followed by the assessment of publicly available documents in all institutions of higher education. These recommendations are intended to promote a culture of research and study quality as well as socially responsible behaviour in research and higher education institutions, and to foster academic integrity, transparency and accountability to stakeholders. Such recommendations were intended to contribute to the mission of research and studies defined in the Law on Higher Education and Research of the Republic of Lithuania, the implementation of the Lithuanian policy of science and studies, and the development and implementation of a coherent system of research and studies.

The main weaknesses in higher education institutions' codes of academic ethics are that they partially encourage bureaucracy in higher education institutions by providing for many more procedures and actions. As Shapoval, Matuliene and 
Juodkaitè-Granskienè (2016) observe, the code of academic ethics must be active, and not a paper. Not only procedures need to be foreseen for each case, but also issues must be actively addressed and violations of academic ethics should be treated very rigorously. As an example, at Mykolas Romeris University, for gross violations of academic ethics, a student is expected to be expelled from the university without a right to be admitted to the university via general admission procedures for up to five years [22]. Codes of academic ethics also contain a general prohibition of discrimination, but often discrimination is defined itemized or simply by quoting the Equal Opportunities Act. Following the notoriety of sexual harassment at a Lithuanian higher education institution, detailed descriptions in codes of ethics were revised. Sexual and other forms of harassment are so far explicitly defined only in the Code of Ethics of the Lithuanian Sports University. It is also noticeable that there is a lack of inspiration for better behaviour, criticism, innovation, and in some cases, there is a greater focus on the negative aspects of ethics, e.g. adherence to the principles of academic ethics is encouraged threatening with punishment. Often, in higher education institutions, everyone knows that there is a code of academic ethics, but in the day-to-day activities, some members of higher education community do not apply it to themselves or to others, even in cases of academic dishonesty. Higher education institutions provide procedures and mechanisms, but the mechanisms provided do not always protect all stakeholders. As Valutyte and Daukšienè (2018) observe, there is a lack of consistency, system and detail in the legislation published by universities. When analysing students' procedural rights in investigating violations of academic ethics, students are usually only given a few basic procedural rights, in some cases these rights and responsibilities are discussed in university regulations that are not even publicly available.

There are also positive things about the codes of academic ethics adopted by several institutions of higher education. Some higher education institutions have also considered the foreign and international experience in the field of regulation of academic ethics, implementation of the provisions of academic ethics and detection of violations of academic ethics when drafting codes of ethics. Higher education institutions note that they have applied the Code of Ethics for Researchers of the Lithuanian Academy of Sciences and the European Union Code of Ethics for Socio-Economic Research [34], European Charter for Researchers and Code of Conduct for the Recruitment of Researchers (2006), The European Science Foundation's Code of Conduct for Research Integrity, etc.

In addition to the application of the Code of Academic Ethics, a number of other measures have been taken to reduce corruption and academic dishonesty. To reduce corruption in higher education, in 
2017 the Lithuanian Mystery of Education and Science conducted an anti-corruption analysis and evaluated the issuance of permits to conduct studies and/or study related activities. On October 19, 2018, the Minister of Education and Science of the Republic of Lithuania approved the Order No. V-843 "Action Plan for Corruption Prevention Measures of 2018-2020 of the Ministry of Education and Science of the Republic of Lithuania". The measures provided for in this plan systematically contribute to the reduction of corruption and partially contribute to reducing the manifestations of hidden forms of corruption.

According to our study, in Lithuania, $48 \%$ of students did not read the code of academic ethics; $27 \%$ of the respondents did not know who to consult with on academic ethics; and $42 \%$ never did that. If we compared them to Lithuanian students studying abroad, the situation would be different: only $33 \%$ of Lithuanian students studying in foreign higher education institutions had not read the code of academic ethics; $8 \%$ did not know who to consult on academic ethics and $27 \%$ did not consult with the teachers on these issues. The data suggests that in many European universities much more attention is paid to the issues of academic ethics, and when our students come to those universities on different student exchange programmes, they have to know those matters.

All Lithuanian and foreign higher education institutions investigated have units responsible for the prevention of academic dishonesty. Information on the functions and activities of these units is made public. Higher education institution websites and other newsletters contain announcements of information seminars and/or events at the University and other institutions aimed at preventing academic dishonesty. However, teachers and students investigated give inconsistent answers on measures to prevent academic dishonesty in higher education institutions. Eighteen percent of teachers working in Lithuanian higher education institutions and $17 \%$ of visiting teachers at foreign higher education institutions responded that their higher education institution had a separate module on academic integrity; $30 \%$ of teachers of Lithuanian higher education institutions mentioned that there were events for students about academic ethics, students were introduced to preventive measures of academic dishonesty, whereas in foreign higher education institutions as many as $70 \%$ the teachers surveyed replied that such events took place in their higher education institutions. However, only $24 \%$ of Lithuanian teachers and $10 \%$ of teachers from foreign higher education institutions reported that similar information seminars and events for teachers were held at their higher education institutions.

Measures of academic dishonesty applied in Lithuanian higher education institutions are mainly informative, and this information often remains misunderstood and not internalized by most students and 
even faculty, and consequently not applied in practice. This suggests that despite the availability of measures to prevent academic dishonesty and the availability of information at Lithuanian and foreign universities, due to differences in general and academic culture and other identified factors, students are not always able to apply the knowledge they receive in practice.

\section{CONCLUSION}

On their websites, higher education institutions publish all documents that regulate their activities including studies, which allows to prevent or partially reduce the existence of not only visible corruption but also hidden forms of corruption. As a preventive measure in higher education, members should be made more aware of the code of ethics and internal rules of work. However, various forms, such as thematic training, seminars or surveys, should be used systematically to fight corruption. It is also necessary to foresee how and where ethical violations will be publicized to academia and society in order to demonstrate transparency in higher education.

\section{REFERENCES}

1. Anderson, M. S., Oju, E. C., Falkner, T. M. R. (2001). Help from faculty: Findings from Acadia Institute Graduate education Study. Science and Engineering ethics. 7(4), 487504.

2. Bikulčiūtè, R. (2013). Akademinio nesąžiningumo problema aukštajame moksle: užsienio patirtis sprendimams Lietuvoje. Vilnius: Vilniaus universitetas, Vilniaus universiteto Studentų atstovybè. Prieiga internetu http://vusa.lt/uploads/user/files/naujienoms/akademinis_saziningumas._uzsienio_patirtis_spre ndimams_lietuvoje.pdf

3. Denisova-Schmidt, E. (2016). The slippery business of plagiarism. The Boston College Center for International Higher Education.

4. Denisova-Schmidt, E. (2017). The challenges of academic integrity in higher education: Curent trends and prospects. The Boston College Center for International Higher Education.

5. Denisova-Schmidt, E., \& Prytula, Y. (2017). Ukraine: Endemic Higher Education Corruption. International Higher Education, 90, 16-18. doi: http://dx.doi/org/10.6017/ihe.2017.90.9745

6. Europos mokslininkų chartija ir Mokslininkų prièmimo i̇ darbą elgesio kodeksas (2006)

7. https://cdn3.euraxess.org/sites/default/files/brochures/kina21620b4c_lt.pdf

8. Lietuvos studentu sajunga (2013) [Lithuanian National Union of Students](2013). Akademinio sąžiningumo indeksas 2013[AcademicIntegrityIndex 2013]. Retrieved from http://www.lss.lt/wp-content/uploads/2013/01/ASI-tyrimo-pristatymo-medžiaga.doc

9. Lietuvos korupcijos žemèlapis 2014 (2014). Gyventojų apklausa [Lithuanian Map of Corruptionin 2014. Population Survey] (2014). Vilmorus: visuomenès nuomonès ir rinkos tyrimai.

10.LR Akademinès etikos ir procedūru kontrolieriaus ataskaita (2017). Akademinès etikos kodeksų ir susijusios informacijos pateikimas mokslo ir studijų institucijose.

11.http://www.etika.gov.lt/wp-content/uploads/2016/02/etikos-kodeksai-Ikelimui.pdf

Higher education community documents available to academic community aiming at increasing academic integrity literacy and preventing corruption of Lithuania 
12.Lietuvos Respublikos akademinès etikos ir procedūrų kontrolieriaus $2015 \mathrm{~m}$. kovo 31 d. issakymu Nr. V-16, patvirtintos Mokslo ir studijų institucijų akademinès etikos kodeksų prièmimo, igyvendinimo ir priežiūros rekomendacijos.

13.http://www.etika.gov.lt/wp-content/uploads/2015/04/Rekomendacijos.pdf

14.Lietuvos Respublikos Švietimo ir mokslo ministrès $2018 \mathrm{~m}$. spalio19 d. isakymas Nr. V-843 Dèl Lietuvos Respublikos švietimo ir mokslo ministerijos korupcijos prevencijos priemonių 2018-2020 metų veiksmu plano.

15.https://www.smm.lt/uploads/documents/veikla/korupcijos_prevencija/Isakymas_korup c_prevenc.pdf

16.Lietuvos Respublikos švietimo ir mokslo ministro $2005 \mathrm{~m}$. gruodžio $5 \mathrm{~d}$. ịsakymas Nr. ISAK-2485 Dèl rekomendacijų akademinès etikos kodeksams patvirtinimo. Negalioja de jure.

17.https://e-seimas.lrs.lt/portal/legalAct/lt/TAD/TAIS.267686

18.Lietuvos Respublikos Seimo nutarimas $2011 \mathrm{~m}$. rugsèjo 15 d. Nr. XI-1583 Dèl Lietuvos Respublikos akademinès etikos ir procedūru kontrolieriaus tarnybos issteigimo ir Lietuvos Respublikos akademinès etikos ir procedūru kontrolieriaus tarnybos nuostatų patvirtinimo.

19.https://eseimas.lrs.lt/portal/legalActPrint/lt?jfwid=13iq21 zn01\&actualEditionId=tJpalsCFjN\&docume ntId=TAIS.406672\&category $=$ TAD

20.Mohamedbhai, G. (2015). Higher education: A hotbed of corruption? Inside Higher Education. Prieiga internetu https://www.insidehighered.com/blogs/world-view/highereducation-hotbed-corruption

21.Mrazauskaitè, R. (2015). Akademinis sąžiningumas - skaidresnès Lietuvos link. TransparencyInternational Lietuvos skyrius. Retrieved from http://www.transparency.lt/wpcontent/uploads/2015/12/Akademinis-saziningumas-Skaidresnes-Lietuvos-link1.pdf

22. Mykolo Riomerio universiteto Senato $2011 \mathrm{~m}$. sausio 27 d. nutarimas Nr. 1SN-17 Dèl Mykolo Riomerio universiteto studijų tvarkos patvirtinimo (2016 m. rugsėjo $27 \mathrm{~d}$. redakcija)

23.https://www.mruni.eu/mru_lt_dokumentai/centrai/akademiniu_reikalu_centras/teises_ aktai/Studiju_tvarka_akt_redakc_2016_09_27.pdf

24.National Council of Teachers of English [NCTE](2013). The NCTE definition of 21st century literacies. Retrieved from http://www.ncte.org/positions/statements/21stcentdefinition

25.Osipian, A. L. (2008). Corruption in Higher Education: does it differ across the nations and why? Research in Comparative and International Education, 3(4), 345-365. http://dx.doi.org/10.2304/rcie.2008.3.4.345

26.Petrov, G., \& Temple, P. (2004) Corruption in Higher Education: Some findings from the states of the former Soviet Union. Higher Education Management and Policy, 16(1), 8294.

27.Rumyantseva, N. L. (2005). Taxonomy of corruption in higher education. Peabody Journal of Education, 80(1), 81-92.

28. Shapoval, R., Matulienè, S., Juodkaitè-Granskienè, G. (2016). Ukrainian Higher Education Law: Key Highlights and Relationships with Lithuanian Science and Study Policy. Pedagogika, 2016, 121(1), p. 198-208.

29. Sawahel, W. (2018). Roadmap for corruption-free higher education proposed. University World News: The Global Window on Higher Education, 505. Prieiga internetu http://www.universityworldnews.com/article.php?story=20180511105847226

30.Seniwoliba, J. A., \& Boahene, B. E. (2015). Manifestation of corruption in higher education: The role of the University administrator. Research Journal of Educational Studies and Review, 1(3), 78-88.

31.Silova, I., Johnson, M. \& Heyneman, S. (2007) Education and the crisis of social cohesion in Azerbaijan and Central Asia. Comparative Education Review, 51(2), 159-180. http://dx.doi.org/10.1086/512022

(C) Kristina Mejeryte-Narkeviciene \& Diana Karanauskiene \& Vida Cesnaitiene, 2019 
32. Tanaka, S. (2001). Corruption in education sector development. A suggestion for participatory strategy. The International Journal of Educational Management, 15(4), 158-166.

33. Tannenberg, M. (2014). Role of universities in the fight against corruption. The Global Window on Higher Education, 343. Prieiga internetu http://www.universityworldnews.com/article.php?story=20141113110707222

34.The European Code of Conduct for Research Integrity (2017). http://www.allea.org/wp-content/uploads/2017/03/ALLEA-European-Code-of-Conduct-forResearch-Integrity-2017-1.pdf

35. The University of Newcastle (2008). Student AcademicI ntegrity - Policy 000608. Retrieved from http://www.newcastle.edu.au/policylibrary/000608.html

36. Transparency International. FAQs on Corruption. Prieiga internetu [2018-06-19] https://www.transparency.org/whoweare/organisation/faqs_on_corruption/2/\#defineCorruptio $\mathrm{n}$

37. Transparency International Global Corruption Barometer 2013: Report (2013). Prieiga internetu https://www.transparency.org/gcb2013/report

38. Transparency International 2013 Global Corruption Report: Education (2013). Prieiga internetu https://www.transparency.org/gcr_education/content/higher

39.Valutytė R., Daukšienė I. (2018). Studentų procedūrinių teisių užtikrinimo tiriant akademinès etikos pažeidimą teisinès prielaidos. Jurisprudencija/Jurisprudence, 2018, 25(1), p. 154-171.

МЕЙЕРІТЕ - НАРКЯВІЧЕНЕ, КРІСТІНА - викладач кафедри менеджменту спорту і туризму, Литовський університет спорту (Каунас, Литва)

E-mail: kristina.mejeryte@1su.1t

ORCID 0000-0003-0629-3265

КАРАНАУСКЕНЕ, ДІАНА - доцент кафедри Фізичної і соціальної освіти, Литовський університет спорту (Каунас, Литва)

E-mail: diana.karanauskiene@1su.lt

ORCID 0000-0002-9346-487X

ЧЕСНАЙТЕНЕ ВІДА - доцент кафедри Фізичної і соціальної освіти, Литовський університет спорту (Каунас, Литва)

E-mail: vida.cesnaitiene@ @ lsu.lt

ORCID 0000-0003-0996-0449

\section{ПІДВИЩЕННЯ ГРАМОТНОСТІ АКАДЕМІЧНОЇ ЧЕСНОСТІ І ПОДОЛАННЯ МОЖЛИВИХ ПРОЯВІВ КОРУПЦІЇ В СИСТЕМІ ВИЩОЇ ОСВІТИ ЛИТВИ}

Анотація. В останні роки у системі вищої освіти надзвичано актуальними $\epsilon$ проблеми грамотності академічної чесності і боротьби 3 корупцією. У внутрішній i зовнішній політиці Литви виражається зацікавленість у скороченні корупції з метою покращення міжнародного іміджу Литви у всіх секторах. В дослідженнях останніх років не вистачає просвітництва громадськості 3 антикорупційих тем, а імідж безпокараності надзвичайно актуальний. В системі освіти корупція проявляється у багатьох формах та вимірах. У всіх випадках корупція підриває якість освіти i, отже, впливає на соціальний та економічний розвиток суспільства. Мета дослідження в тому, щоб проаналізувати документацію, доступну спільноті вищої освіти, 3 метою підвищення грамотності у питаннях академічної чесності і подолання можливої корупції у системі вищої освіти, а, отже, оцінити їх наглядність і доступність для наукових кіл і суспільства. Завданнями є: проаналізувати документи, доступні для спільнот вищих навчальних закладів, пов'язаних з цілісністю академічної грамотності,

Higher education community documents available to academic community aiming at increasing academic integrity literacy and preventing corruption of Lithuania 
оцінити наглядність і доступністьь документів для академічних кіл і громадськості, визначити дані документи, проаналізувати i дослідити членами академічного товариства. Аналіз останніх досліджень і публікацій. Академічна грамотність і подолання корупції у вищій освті є зростаючою темою в освітянських дослідженнях. I. Сілова, М. Джонсон, С. Хейнеман (2007), Е. Денісова-Шмідт (2016) більше підкреслюють, як корупція впливає на ефективність економіки. Р. Бікульчюте і Р. Мразаускайте (2013) виявили проблеми грамотності академічної чесності. Н.Л. Румянцева (2005) представила таксономію корупції у системі вищої освіти. А.Л. Осипян (2008), С. Танака (2001), Г. Мохамедбхай (2015) та інші відмічали про виявлення прихованої і відкритої корупції чи корупційні форми. Висновки. На своїх веб-сайтах вищі навчальні установи публікують всі документи, що регламентують їх діяльність, у тому числі дослідження, які дозволяють подолати не тільки відкриту корупцію, але й приховану форму корупції чи, зокрема, іiі зменшити. Підвищена освідомленість про етичний кодекс та внутрішні правила процедури може бути використана у якості превентивного заходу. Проте у боротьбі з корупцією слід систематично використовувати різноманітні форми, такі, як тематичні тренінги, семінари чи опитування.

Ключові слова: грамотність академічної чесності, академічна чесніть, корупція у вищій освіті, приховані форми корупції

МЕЙЕРИТЕ - НАРКЯВИЧЕНЕ, КРИСТИНА - преподаватель кафедры менеджмента спорта и туризма, Литовский университет спорта (Каунас, Литва)

E-mail: kristina.mejeryte@ @ lsu.lt

ORCID 0000-0003-0629-3265

КАРАНАУСКЕНЕ, ДИАНА - доцент кафедры Физического и социального образования, Литовский университет спорта (Каунас, Литва)

E-mail: diana.karanauskiene@1su.lt

ORCID 0000-0002-9346-487X

ЧЕСНАЙТЕНЕ, ВИДА - доцент кафедры Физического и социального образования, Литовский университет спорта (Каунас, Литва)

E-mail: vida.cesnaitiene@ lsu.lt

ORCID 0000-0003-0996-0449

\section{ПОВЫШЕНИЕ ГРАМОТНОСТИ АКАДЕМИЧЕСКОЙ ЧЕСТНОСТИ И ПРЕОДОЛЕНИЯ ВОЗМОЖНЫХ ПРОЯВЛЕНИЙ КОРРУПЦИИ В СИСТЕМЕ ВЫСШЕГО ОБРАЗОВАНИЯ ЛИТВЫ}

Аннотация. В последние годы в системе высшего образования очень актуальны проблемы грамотности академической честности и борьбы с коррупцией. Во внутренней и внешней политике Литвы выражается заинтересованность в сокращении коррупции с целью улучшения международного имиджа Литвы во всех секторах. В исследованиях последних лет не хватает просвещения общественности по антикорупционным темам, а имидж безнаказанности очень актуален. В системе образования коррупция проявляется во многих формах и измерениях [37]. Во всех случаях коррупция подрывает качество образования и, следовательно, влияет на социальное и экономическое развитие общества.

Цель исследования в том, чтобы проанализировать документацию, доступную сообществам высшего образования, с целью повышения грамотности в вопросах академической честности и предотвращения возможной коррупции в системе высшего образования, а также оценить их наглядность и доступность для научных кругов и общества. Задачами являются: проанализировать документы, доступные для сообществ высших учебных заведений, связанных с целостностью академической грамотности,

(C) Kristina Mejeryte-Narkeviciene \& Diana Karanauskiene \& Vida Cesnaitiene, 2019 
оценить наглядность и доступность документов для академических кругов и общественности, определить были ли имеющиеся документы, проанализированы и исследованы членами академического сообщества.

Анализ последних исследований и публикаций. Академическая грамотность и предотвращение коррупции в высшем образовании является растущей темой в образовательных исследованиях. И. Силова, М. Джонсон, С. Хейнеман (2007), Е. Денисова-Шмидт (2016), больше подчеркивают, как коррупция влияет на эффективность экономики. Р. Бикульчюте и Р. Мразаускайте (2013) выявили проблемы грамотности академической чеснасти. Н.Л. Румянцева (2005) представляла таксономию коррупции в системе высшего образования. А.Л. Осипян (2008), С. Танака (2001), Г. Мохамедбхай (2015) и другие писали о проявлениях скрытой и открытой коррупции или коррупционных формахю

Выводы. На своих веб-сайтах высшие учебные заведения публикуют все документы, регламентирующие их деятельность, в том числе исследования, которые позволяют предотвратить не только видимую коррупцию, но и скрытые формы коррупциию или их в частности уменьшить. Повышенная осведомленность об этическом кодексе и внутренних правилах процедуры может быть использована в качестве превентивной меры. Однако в борьбе с коррупцией следует систематически использовать различные формы, такие как тематические тренинги, семинары или опросы.

Ключевые слова: грамотность академической честности, академическая честность, коррупция в высшем образовании, скрытые формы коррупции.

Received date 12.09.2019

Accepted date 10.10.2019

Published date 15.11.2019

Higher education community documents available to academic community aiming at increasing academic integrity literacy and preventing corruption of Lithuania 